\title{
DIGITAL CONTENT CONTRACTS AND CONSUMER PROTECTION: STATUS QUO AND WAYS FURTHER
}

\author{
Neda Zdraveva, PhD, Associate Professor \\ Iustinianus Primus Law Faculty, Ss. Cyril and Methodius University \\ Bul. Goce Delchev 9b, 1000 Skopje, North Macedonia \\ n.zdraveva@pf.ukim.edu.mk
}

\begin{abstract}
One of the effects of the COVID-19 crisis is the significant acceleration of e-commerce. The number of companies and the varieties of products in the online markets increased, as well as the numbers of consumers and consumers' segments diversification. The e-commerce in pandemic times offered clear benefits and opportunities for the consumers. It also created situations where the lack of confidence in e-commerce may intensify. This comes from the consumers' uncertainty on their key contractual rights and it is particularly a case when it comes to the contracts for supply of digital content and digital services.
\end{abstract}

The European Union considered that legal certainty for consumers (and businesses) will increase by full harmonisation of key regulatory issues and that this would lead to growth of the potentials the e-commerce has on the common market. Aiming to achieve a genuine digital single market the Council of the European Union and the European Parliament in May 2019 have adopted the Directive (EU) 2019/770 on certain aspects concerning contracts for the supply of digital content and digital services (the "Digital Content Directive") and the Directive (EU) 2019/771 on certain aspects concerning contracts for the sale of goods (the "Sales of Goods Directive") that regulate the supply of digital content and digital services and sale of goods with digital elements, respectively. Both directives lay down specific rules on the conformity of digital content or a digital service i.e., goods with digital elements with the contract, remedies in the cases of a lack of conformity or a failure to supply, as well as the modalities for the exercise of those remedies.

The paper analyses the mechanisms for regulation of the contracts for the supply of digital content and digital services and the specific rights and obligations of the parties to these contracts. The main objective of the research is to assess to which extent these mechanisms are novelty in the European Consumer Law and to examine the obstacles that the application of consumer law to digital content contracts may encounter.

Keywords: digital content, digital service, digital content contract, consumer protection 


\section{INTRODUCTION}

Eurostat estimates that at least $65 \%$ of the citizens of the European Union member states ${ }^{1}$ made at least one online purchase in the last 12 months, while at least $53 \%$ of them made at least one purchase in the last 3 months of $2020 .^{2}$ The numbers show steady rise of the use of the Internet as a mean for purchase in the past 10 years. For example, in 2010 only $40 \%$ of the citizens made at least one online purchase in the last 12 months, which rose to $60 \%$ in 2019 , and $27 \%$ of the citizens made at least one purchase in the last 3 months in 2010, which rose to $49 \%$ in $2019 .{ }^{3}$ Off all online purchases (in the last 3 months) it is estimated that $37 \%$ were clothes (including sport clothing), shoes or accessories, $16 \%$ of the online purchases were furniture, home accessories or gardening products, and the same percentage were printed books, magazines or newspapers. Total of $17 \%$ of the purchases were deliveries from restaurants, fast-food chains, catering services. Approximately one third of all purchases were related to digital content and digital services $-15 \%$ of purchases were music as a streaming service or downloads and $18 \%$ were films or series as a streaming service or downloads. ${ }^{4}$ Most of the online pucrases (37\%) were of cost of 100 euro or more. ${ }^{5}$ In 2020 the online sales to consumers (B2C) were made available by $20 \%$ of all enterprises established in the EU that have more than 10 employees (without the financial sector). ${ }^{6}$ The OECD position is that the COVID-19 crisis accelerated an expansion of e-commerce towards new firms, customer segments and types of products. ${ }^{7}$ It is considered that consumer trust is essential to the proper functioning of markets. This is particularly true in e-commerce, where consumers are unable to inspect products at a distance. ${ }^{8}$

1 Data on the current 27 member states of the European Union.

2 Internet purchases by individuals (2020 onwards), Eurostat, [https://ec.europa.eu/eurostat/databrowser/view/isoc_ec_ib20/default/table?lang=en], Accessed 15 March 2021.

3 Internet purchases by individuals (until 2019), Eurostat, [https://appsso.eurostat.ec.europa.eu/nui/ submitViewTableAction.do], Accessed 15 March 2021.

4 Internet purchases - goods or services (2020 onwards), Eurostat, [https://appsso.eurostat.ec.europa.eu/ nui/show.do?dataset=isoc_ec_ibgs\&lang=en], Accessed 15 March 2021.

5 Internet purchases - money spent (2020 onwards), Eurostat, [https://appsso.eurostat.ec.europa.eu/ nui/submitViewTableAction.do], Accessed 15 March 2021.

6 E-commerce sales, Eurostat, [https://ec.europa.eu/eurostat/databrowser/view/isoc_ec_eseln2/default/ table?lang=en] Accessed 15 March 2021.

7 E-commerce in the times of COVID-19, OECD, [https://www.oecd.org/coronavirus/policy-responses/e-commerce-in-the-time-of-covid-19-3a2b78e8/], Accessed 15 March 2021.

8 Protecting online consumers during the COVID-19 crisis, OECD, [https://www.oecd.org/coronavirus/policy-responses/protecting-online-consumers-during-the-covid-19-crisis-2ce7353c/], Accessed 15 March 2021. 
The need for increasing consumers' trust in the e-commerce was one of the key factors in developing harmonised rules aimed to enable the potentials of the digital single market in the EU to be realized to full extent. In 2015 the European Commission proposed a directive on contracts for the supply of digital content and digital services ${ }^{9}$ and a directive concerning certain aspects on online and other distance sales contracts for the sale of goods ${ }^{10}$. The proposals were part of the Commission's Digital Single Market Strategy, aiming to "reduce barriers and offer more opportunities for consumers and businesses to contract across European Union borders in a legal, safe, secure and affordable way." 11 One can argue that this approach (re)emphasises the role of the consumer law on facilitating trade ${ }^{12}$ and is reflected in the policy that aims at totally harmonising consumer law at the EU level so as to establish one set of rules applicable in all Member State. ${ }^{13}$ The proposals were also consistent with the Commission's 2018 New Deal for Consumers strategy ${ }^{14}$, where the importance of these proposals "to provide consumers with clear and effective rights when accessing digital content and to ensure that both consumers and businesses can rely on uniform and effective rules across Europe" was emphasised and both proposals were expressly acknowledged as "a central element of the Digital Single Market strategy aiming to modernise consumer contract rules". Both of the proposals, aiming for maximum harmonisation, sought to ensure that traders in the Internal Market are not deterred from cross-border trading by differences in mandatory national contract laws, while

9 Proposal for a Directive of the European Parliament and of the Council on certain aspects concerning contracts for the supply of digital content; COM/2015/0634 final - 2015/0287 (COD); hereinafter: proposal Digital Content Directive).

10 Proposal for a Directive of the European Parliament and of the Council on certain aspects concerning contracts for the online and other distance sales of goods; COM/2015/0635 final - 2015/0288 (COD); hereinafter: proposal Directive on Online Sale of Goods.

11 Communication from the Commission to the European Parliament, the Council, the European Economic and Social Committee and the Committee of the Regions: A Digital Single Market Strategy for Europe, COM (2015) 192 final.

12 The ECJ treated national consumer laws as potential obstacle to movement within the Community, justified only when necessary, to inter alia protect the consumers (Case 120/78 Rewe-Zentral AG v Bundesmonopolverwaltung für Branntwein, [1979] ECR 00649, para. 8), thus the following consumer protection directives aimed to remedy any disparity between legislation that may directly affect the functioning of the common market (see for example Recitals 2 of Council Directive 85/577/EEC of 20 December 1985 to protect the consumer in respect of contracts negotiated away from business premises, OJ L 372).

13 Rott, P., The EU Legal Framework for the Enforcement of Consumer Law in: Micklitz, H-W.; Saumier, G., Enforcement and Effectiveness of Consumer Law, Ius Comparatum - Global Studies in Comparative Law, Volume 27, Springer, 2018, p. 252.

14 Communication from the Commission to the European Parliament, the Council, and the European Economic and Social Committee: A New Deal for Consumers, Brussels, 11.4.2018 COM (2018) 183 final. 
providing consumers with a higher level of protection. The fact that 'rules on the supply of digital content are generally absent in European private law systems"15 as are 'remedies for non-conformity of digital content" ${ }^{16}$ are seen the reasons for urgency in the matter. There are, however, substantiated lines of reasoning that the main motivation behind the proposals is not the lack of consumer protection provisions at the national level, but rather "the stimulation of the EU economy, while the creation of consumer trust in the internal market is being used as a means to achieve growth." 17

It took almost four years the directives to be adopted. While the proposal Digital Content Directive was introducing novelties in the consumer contract law, the proposal Directive on Online Sale of Goods involved intervention in a field that was already regulated in the consumer contract law of the EU and the member states. ${ }^{18}$ Reflecting on the debates on these proposals, one may conclude that they arose, inter alia, from the fact that the proposals aimed to maximum harmonisation while the national legislation had existing rules that went beyond and may (potentially) reduce the consumer protection ${ }^{19}$. At the time, there were five coexiting regimes that may be applicable to sales contracts and a new one was being introduced by the proposal Digital Content Directive. The fact that the scope of the proposal Directive on Online Sale of Goods included only on the distance sales contracts made the whole system seem unworkable, so it was argued that "the Member States will only agree to adopt the proposal Directive on Online Sale of Goods if its scope is enlarged to include also on- and off-premises contracts". ${ }^{20}$

15 Giliker, P., Adopting a Smart Approach to EU Legislation: Why Has It Proven So Difficult to Introduce a Directive on Contracts for the Supply of Digital Content?, in: Synodinou, T-E.; Jougleux, P.; Markou, C.; Prastitou, T. (eds.), EU Internet Law in the Digital Era Regulation and Enforcement, Springer, 2020, p.300.

16 Oprysk, L., "Digital" Exhaustion and the EU (Digital) Single Market, in. Synodinou, T-E.; Jougleux, P.; Markou, C.; Prastitou, T. (eds.), EU Internet Law in the Digital Era Regulation and Enforcement, Springer, 2020, p.172.

17 Lehmann, M., A Question of Coherence: The Proposals on EU Contract Law Rules on Digital Content and Online Sales, Maastricht Journal of European and Comparative Law, vol. 23, no. 5, 2016, p. 755-756.

18 The rules established by the Directive 1999/44/EC of the European Parliament and of the Council of 25 May 1999 on certain aspects of the sale of consumer goods and associated guarantees, [1999] OJ L 171/12. (hereinafter: Consumer Sales Directive or Directive 1999/44/EC).

19 See further Beale, H., Scope of application and general approach of the new rules for contracts in the digital environment, European Parliament; Directorate General for Internal Policies; Policy Department C: Citizens' Rights and Constitutional Affairs, PE 536.493, p. 5.

20 Loos, M., European Harmonisation of Online and Distance Selling of Goods and the Supply of Digital Content, Amsterdam Law School Research Paper No. 2016-27, Centre for the Study of European Contract Law Working Paper Series No. 2016-08, p. 2 Available at SSRN: https://ssrn.com/ abstract=2789398 or http://dx.doi.org/10.2139/ssrn.2789398. 
Finally, in January 2019, the Council and the Parliament agreed on "an ambitious yet balanced compromise between guaranteeing rights for European consumers while creating new business opportunities for EU companies. Consumers will now be better protected when they buy a shirt in a shop, a smart fridge online or download music. Companies will be able to cut red tape when they want to expand and start selling across the Union." ${ }^{21}$ Directive (EU) 2019/770 of the European Parliament and of the Council of 20 May 2019 on certain aspects concerning contracts for the supply of digital content and digital services ${ }^{22}$ and Directive (EU) 2019/771 of the European Parliament and of the Council of 20 May 2019 concerning contracts for the sale of goods, amending Regulation (EU) 2017/2394 and Directive 2009/22/EC, and repealing Directive 1999/44/EC ${ }^{23}$ were published in the Official Journal of the European Union on 22 May 2019.

\section{SCOPE OF THE DIGITAL CONTENT DIRECTIVE}

The Digital Content Directive regulates the contracts between traders and consumers for the supply of digital content or digital services, and specifies the rules on conformity of digital content or a digital service with the contract, remedies in the event of a lack of conformity or a failure to supply, and the modalities for their exercise, and the modification of digital content or a digital service. ${ }^{24}$ The Sale of Goods Directive lays down rules on certain requirements concerning contracts for the sale of goods, where the goods with digital elements are included, as well as rules about the conformity of goods, remedies for lack of conformity or failure to supply and modalities for their exercise, as well as the commercial guarantees ${ }^{25}$. The rules of both directives are complimentary to each other $^{26}$. On the obligations

${ }^{21}$ Tudorel Toader, Minister of Justice of Romania, Press Release of the Council of the EU, 'Council and Parliament agree on new rules for contracts for the sale of goods and digital content' 29 January 2019, [https://www.consilium.europa.eu/en/press/press-releases/2019/01/29/council-and-parliament-agreeon-new-rules-for-contracts-for-the-sales-of-goods-and-digital-content/] Accessed 1 April 2021.

22 Directive (EU) 2019/770 of the European Parliament and of the Council of 20 May 2019 on certain aspects concerning contracts for the supply of digital content and digital services, OJ L 136 (hereinafter: Digital Content Directive or Directive (EU) 2019/770 or DCD).

23 Directive (EU) 2019/771 of the European Parliament and of the Council of 20 May 2019 on certain aspects concerning contracts for the sale of goods, amending Regulation (EU) 2017/2394 and Directive 2009/22/EC, and repealing Directive 1999/44/EC, OJ L 136 (hereinafter: Sale of Goods Directive or Directive (EU) 2019/771 or SGD).

24 Art. 1 of DCD.

25 Art. 1 of SGD.

26 Recitals 21 of DCD and Recitals 13 of SGD. 
related to the delivery of goods and remedies in the event of the failure to deliver, the provisions of Directive 2011/83/EU ${ }^{27}$ are applicable ${ }^{28}$.

\subsection{Definition of the contract - Objective scope of the Digital Content Directive}

Regulating the application of Directive (EU) 2019/770, the legislator provides a definition of the digital content/digital service contract as "any contract where the trader supplies or undertakes to supply digital content or a digital service to the consumer and the consumer pays or undertakes to pay a price" 29 .

As per DGD, 'digital content' means data which are produced and supplied in digital form, while 'digital service' means: (a) a service that allows the consumer to create, process, store or access data in digital form; or (b) a service that allows the sharing of or any other interaction with data in digital form uploaded or created by the consumer or other users of that service ${ }^{30}$.

When it comes to the price ${ }^{31}$ to be paid, the Directive, beside payments in money, foresees as a method of payment the digital representations of value (electronic vouchers or e-coupons) to be considered as well. The 'digital representations of value' also include virtual currencies, to the extent that they are recognised by national law. ${ }^{32}$ Beside these novelties related to the price payment, the Directive introduces one more very important novelty in the consumer law - the personal data of the consumer is considered as 'currency' for payment of the price. Namely, the DCD provides that for the supply or undertaking to supply digital content or a digital service by the trader, the consumer to provide or undertake to provide

27 Directive 2011/83/EU of the European Parliament and of the Council of 25 October 2011 on consumer rights, amending Council Directive 93/13/EEC and Directive 1999/44/EC of the European Parliament and of the Council and repealing Council Directive 85/577/EEC and Directive 97/7/EC of the European Parliament and of the Council, OJ L 304 (hereinafter: Directive 2011/83/EU or Consumer Rights Directive) as amended by Directive (EU) 2019/2161 of the European Parliament and of the Council of 27 November 2019 amending Council Directive 93/13/EEC and Directives 98/6/EC, 2005/29/EC and 2011/83/EU of the European Parliament and of the Council as regards the better enforcement and modernisation of Union consumer protection rules, OJ L 328 (hereinafter: Directive 2019/2161).

28 Directive 2011/83/EU is applied for the right of withdrawal and the nature of the contract under which those goods are supplied. DCD is also without prejudice to the distribution right applicable to these goods under copyright law. See Recital 20 of DCD.

29 Article 3(1) of DCD.

30 Art. 2(1)(2) and (3) of DCD.

31 Price in terms of the Directive means money or a digital representation of value that is due in exchange for the supply of digital content or a digital service (Art. 2(1/7) of DCD).

32 Recital 23 of DCD. 
personal data to the trader ${ }^{33}$. By the introduction of this payment mode, the DCD makes the digital content not only the object of the contractual performance, but also a counter-performance. ${ }^{34}$ Considering the fact that such business models provision of digital service for personal data - are used in different forms in a considerable part of the market, the DCD ensures that consumers are, in the context of such business models, entitled to contractual remedies, while fully recognising that the protection of personal data is a fundamental right and that therefore personal data cannot be considered as a commodity. ${ }^{35}$ This novelty of the DCD does not go without criticisms, that are based on the fundamental right nature of the personal data and their protection. It is argued that the compatibility of this regime with the General Data Protection Regulation ${ }^{36}$ is questionable and that it provides legitimisation of a business model hostile to data protection principles. ${ }^{37}$ It is to be noted in this regard, that DCD allows the Member States to determine whether the requirements for the formation, existence and validity of a contract where personal data is used as a commodity, under national law are fulfilled. ${ }^{38}$

\subsection{Parties to the Contract - Subjective Scope of the Digital Content Directive}

In defining the trader ${ }^{39}$ as the party who supplies or undertakes to supply digital content or digital service to the consumer, the Directive (EU) 2019/770 does not introduce new developments in the exiting EU consumer law. However, the Directive introduces the possibility the digital platform providers to be considered traders if they act for purposes relating to their own business and as the direct contractual partner of the consumer for the supply of digital content or a digital service, stipulating that "Member States should remain free to extend the applica-

33 Article 3(1) of DCD .

34 See further Grundmann, S.; Hacker, P., Digital Technology as a Challenge to European Contract Law - From the Existing to the Future Architecture (July 17, 2017). 13 European Review of Contract Law 255-293, Available at SSRN: https://ssrn.com/abstract=3003885.

35 Recital 24 of DCD.

36 Regulation (EU) 2016/679 of the European Parliament and of the Council of 27 April 2016 on the protection of natural persons with regard to the processing of personal data and on the free movement of such data, and repealing Directive 95/46/EC (General Data Protection Regulation), OJ L 119 (hereinafter: GDPR).

37 Drechsler, L., Data As Counter-Performance: A New Way Forward Or A Step Back For The Fundamental Right Of Data Protection?, in: Datenschutz \& LegalTech/ Data Protection \& LegalTech: Digitale Ausgabe zum Tagungsband des 21. Internationalen Rechtsinformatik Symposions IRIS2018 (February ed.), pp. 35-43.

38 Recital 24 of DCD.

39 'trader' means any natural or legal person, irrespective of whether privately or publicly owned, that is acting, including through any other person acting in that natural or legal person's name or on that person's behalf, for purposes relating to that person's trade, business, craft, or profession, in relation to contracts covered by this Directive, Art. 2(1/5) of DCD; Defined as seller in Art. 2(1/3) SGD. 
tion of this Directive to platform providers that do not fulfil the requirements for being considered a trader". ${ }^{40}$

The notion of consumer in the Directive (EU) 2019/770 does not differ from the exiting definitions of 'consumer' in the EU Law and includes "any natural person who, in relation to contracts covered by this Directive, is acting for purposes which are outside that person's trade, business, craft, or profession". ${ }^{41}$ The Member States may extend the protection afforded by this directive to other persons who are not qualified as consumers according to the definition, such as non-governmental organisations, start-ups or SMEs. ${ }^{42}$ This can be done in three ways: (i) extension of the concept of consumer, including legal persons and/or persons acting for professional purposes; (ii) general application of the legal regime(s) irrespective of the nature of the buyer of goods, digital content or digital services; (iii) extension of the protection to other categories of persons, such as micro-enterprises. ${ }^{43} \mathrm{~A}$ challenge may arise, however, when it comes to dual-purpose contacts and the established criterion on predominant use. ${ }^{44}$ The DCD provides that "Member States .... [are] free to determine,..... where the contract is concluded for purposes that are partly within and partly outside the person's trade, and where the trade purpose is so limited as not to be predominant in the overall context of the contract, whether and under which conditions that person should also be considered a consumer" ${ }^{45}$. Compared to this, Directive 2011/83 always considers these persons as consumers ${ }^{46}$. This position of the DCD regarding the dual-purpose contracts, opens the possibility to different approaches and cases where a same person has different position in different Members States.

\section{SUPPLY OF THE DIGITAL CONTENT OR DIGITAL SERVICE AND THEIR CONFORMITY WITH THE CONTRACT}

\subsection{Supply of the digital content or digital service}

The Digital Content Directive provides (Art. 5(1)) that 'the trader shall supply the digital content or digital service to the consumer, unless otherwise agreed,

\footnotetext{
40 Recital 18 of DCD; See also Recital 23 of SGD.

41 Art. 2(6) of DCD; See also Art. 2(2) of SGD.

42 Recital 16 of DCD.

43 Morais Carvalho, J., Sale of Goods and Supply of Digital Content and Digital Services - Overview of Directives $2019 / 770$ and 2019/771 (July 18, 2019)., p. 6; Available at SSRN: https://ssrn.com/abstract $=3428550$ or http://dx.doi.org/10.2139/ssrn.3428550.

44 Case C-464/01 Johann Gruber v Bay Wa AG [2005] ECR I-00439, para. 39.

45 Recital 17 of DCD.

46 Recital 17 of Directive 2011/83/EU.
} 
without undue delay after the conclusion of the contract'. Hence, different modes of supply of digital content or provision of digital service are foreseen: single act or series of single acts of supply $y^{47}$ and continuous supply over a period of time. ${ }^{48}$ It is considered that the trader complied with the obligation to supply when: "(a) the digital content or any means suitable for accessing or downloading the digital content is made available or accessible to the consumer, or to a physical or virtual facility chosen by the consumer for that purpose; or (b) the digital service is made accessible to the consumer or to a physical or virtual facility chosen by the consumer for that purpose." ${ }^{49}$ The digital content or the digital service should be supplied in the most recent version available at the time of the conclusion of the contract, unless otherwise agreed between the parties. ${ }^{50}$

\subsection{Conformity of the digital content or digital service}

Setting clear rules on conformity requirements is one of the cornerstones of the consumer protection. As conformity requirements for tangible goods exist in the EU consumer law since $1999,{ }^{51}$ setting rules on conformity of the digital content or a digital service was long overdue. Beside introduction conformity rules as such, a distinctive characteristic of Directive (EU) 2019/770 is that explicitly separates the conformity assessment criteria in subjective and objective. This is also case with the conformity criteria set in Directive (EU) 2019/771. The conformity assessment criteria themselves are not particular novelty, but both directives add to the existing ones the functionality, compatibility and interoperability requirements for digital content and services and for goods with digital elements.

While the subjective conformity requirements refer to elements resulting directly from the specific relationship between the consumer and the trader, the objective

47 The distinctive element of this category of supply od digital content or digital service is the fact that consumers thereafter have the possibility to access and use the digital content or digital service indefinitely; Recital 56 of DCD.

48 The distinctive element of this category is the fact that the digital content or digital service is available or accessible to consumers only for the fixed duration of the contract or for as long as the indefinite contract is in force. This includes, for example, a two-year cloud storage contract or an indefinite social media platform membership. The element of continuous supply does not necessarily require a longterm supply. For example, cases such as web-streaming of a video clip should be considered continuous supply over a period of time, regardless of the actual duration of the audio-visual file. Cases where specific elements of the digital content or digital service are made available periodically or on several instances during the fixed duration of the contract, or for as long as the indefinite contract is in force, should also be considered a continuous supply over a period of time. Recital 57 of DCD.

49 Article 5(2) of DCD.

50 Article 8(6) of DCD.

51 Introduced by Consumer Sales Directive. 
conformity requirements refer to what could normally be expected for the type of digital content or digital service.

\subsubsection{Subjective requirements for conformity}

The directive sets four subjective conformity requirements ${ }^{52}$ to be used as assessment criteria where applicable. Thus, the digital content or digital service is in conformity with the contract when: (a) it is of the description, quantity and quality, and possess the functionality, compatibility, interoperability and other features, as required by the contract; or (b) it is fit for any particular purpose for which the consumer requires it and which the consumer made known to the trader and the trader accepted it (at the latest at the time of the conclusion of the contract); or (c) it is supplied with all accessories, instructions, including on installation, and customer assistance as required by the contract; or (d) it is updated as stipulated by the contract. ${ }^{53}$

\subsubsection{Objective requirements for conformity}

The objective requirements for conformity ${ }^{54}$ are in addition to complying with any of the subjective requirements. As per $\mathrm{DCD}^{55}$, it will be considered that the objective assessment criteria are met when the digital content or digital service is: (a) fit for the purposes for which digital content or digital services of the same type would normally be used ${ }^{56}$; (b) of the quantity and possess the qualities and performance features the consumer may reasonably expect ${ }^{57}$; (c) supplied along with any accessories and instructions which the consumer may reasonably expect to receive, where applicable; and (d) in comply with any trial version or preview of the digital

\footnotetext{
52 Art. 7 of DCD.

53 Same subjective conformity requirements exist for the goods with digital elements as per Art. 6 of DCD.

54 Art. 8(1) of the DCD.

55 Similarly, the objective conformity requirements for goods with digital elements as per Art. 7 of SGD.

56 In the assessment of this any existing Union and national law, technical standards or, in the absence of such technical standards, applicable sector-specific industry codes of conduct, where applicable, should be taken into account.

57 This includes the qualities and performance features in relation to functionality, compatibility, accessibility, continuity and security, normal for digital content or digital services of the same type and which, given the nature of the digital content or digital service and the public statements made by or on behalf of the trader, or other persons in the chain of transactions, particularly in advertising or on labelling. Exceptions exist when the trader shows that it was not, and could not reasonably have been, aware of the public statement in question; or that the public statement had been corrected in the same or a comparable way by the time of conclusion of the contract; or the decision of the consumer to acquire the digital content or digital service could not have been influenced by the public statement.
} 
content or digital service, made available by the trader before the conclusion of the contract. In the cases when the supply of digital content or digital service is continuous over a period of time, they are to be in conformity throughout the duration of that period. ${ }^{58}$

Having in mind that the digital content and the digital service change very fast and very often, the DCD provides that the trader is obliged to ensure that the consumer is informed of and supplied with updates, including security updates, that are necessary to keep the digital content or digital service in conformity in course of the performance of the contract (in the cases of continuous supply). When it comes to contracts where the digital content/digital service is provided in a single act of supply or a series of individual acts of supply, the trader is obliged to provide updates that the consumer may reasonably expect (given the type and purpose of the digital content/service and taking into account the circumstances and nature of the contract). ${ }^{59}$ Lack of conformity may exist as a result of incorrect integration of the digital content or digital service into the consumer's digital environment. In this case, the trader is liable for lack of conformity if: (a) the integration of the digital content or digital service in the consumer's digital environment was carried out by the trader or under the trader's responsibility; or (b) the integration made by the consumer was incorrect due to shortcomings in the integration instructions provided by the trader ${ }^{60}$.

The failure of the trader to ensure that the digital content or digital service meets the conformity requirements will, in principle, lead to its liability for lack of conformity. Exceptions exist when the reason for the lack of conformity lies with the consumer. Thus, when it comes to updates, the trader will not be liable for any lack of conformity if the consumer failed to install, within a reasonable time, the updates supplied by the trader, provided that the consumer was properly informed by the trader that: (a) updates are available and what are the consequences of the failure to install it; and (b) how the update should be to installed. ${ }^{61}$ In addition, where the consumer was informed before the conclusion of the contract and agreed, expressly and separately, accepted that a particular characteristic of the digital content or digital service deviates from the objective requirements for conformity, the trader will not be liable for that lack of conformity. ${ }^{62}$

\footnotetext{
$58 \quad$ Art. 8(4) of DCD.

59 Art. 8(2) of DCD.

60 Art. 9 of DCD.

61 Art. 8(3) of DCD.

62 Art. 8(5) of DCD.
} 


\subsubsection{Legal defects as lack of conformity}

The DCD includes the legal defects in the concept of lack of conformity. Thus, as per Art. 10, the consumer is entitled to the remedies for lack of conformity where the use of the digital content or digital service is restricted (limited or prevented) because rights of a third party, in particular intellectual property rights, have been violated by the digital content/service. The rational of this provision lies in the fact that the digital content and digital services are subject to intellectual property rights. When these rights are violated the third party may invoke a set of protection mechanisms that will result in the consumer being prevented or limited to use the digital content or digital service. When this is the case, in accordance with the subjective and objective requirements for conformity, the consumer is entitled to the remedies for the lack of conformity. Liability for lack of conformity will be the consequence unless the national law provides for nullity or rescission of the contract for the supply of the digital content or digital service with legal defects. ${ }^{63}$

\section{LIABILITY OF THE TRADER FOR BREACH OF CONTRACT}

The trader is liable to the consumer for failure to supply the digital content or digital service and in the event of a lack of conformity of the digital content or digital service.

\subsection{Establishment of the time of breach}

The supply of the digital content or digital service to the consumer, unless otherwise agreed, should be without undue delay after the conclusion of the contract. ${ }^{64}$ The trader would be in a breach of contract if the digital content or the digital service is not provided at time for act of supply, being single or one in series, or does not start the continuous supply of content or service.

When it comes to the lack of conformity of the digital content or digital service, it is necessary to determine the relevant time when the lack is established, having in mind the modalities of the supply. Thus, where a contract provides for a single act of supply or a series of individual acts of supply, the conformity of the digital content or digital service to the requirements is assessed at the time of supply. Therefore the trader is liable only for lack of conformity which exists at the time when the single act of supply or each individual act of supply takes place. ${ }^{65}$ If, under national law, the trader is only liable for a lack of conformity that becomes

\footnotetext{
63 See also Recital 54 of DCD.

64 Art. 5(1) of DCD.

65 Art. 11 (2) of DCD; Same period is foreseen in Art. 10 (1) of SGD.
} 
apparent within a period of time after supply, the Directive in Art. 11(2) provides that this period shall not be less than two years from the time of supply. ${ }^{66}$ In the cases of continuous supply over a period of time, the trader is liable for a lack of conformity, that occurs or becomes apparent within the period of time during which the digital content or digital service is to be supplied under the contract. ${ }^{67}$

\subsection{Time limits for liability for lack of conformity}

In order to ensure legal certainty, Recital 56 of the Directive provides that traders and consumers should be able to rely on a harmonised minimum period during which the trader should be held liable for a lack of conformity. In relation to contracts which provide for a single act of supply or a series of individual acts of supply of the digital content or digital service, as per Article 11(2), traders should be liable for not less than two years from the time of supply, provided that under the national law, the trader is liable for any lack of conformity that becomes apparent within a period of time after supply. If the exercise of the rights the consumer has in cases of lack of conformity, under the national law, is subject to limitation period, the national law should ensure that the limitation period allows the consumer to exercise the remedies for any lack of conformity that occurs or becomes apparent during the period of supply. ${ }^{68}$

\subsection{Burden of proof}

The burden of proof with regard to whether the digital content or digital service meets the conformity requirements, in principle is on the trader. The DCD recognizes the fact that digital content and digital services have a specific nature and are highly complex, as require specific know-how, technical information and high-tech assistance, so the position of the trader is better than the consumer's when it comes to assessing if and why the digital content or digital service is not supplied or is not in conformity. ${ }^{69}$ Therefore, in the event of a dispute between the trader and the consumer on the (lack of) conformity, the consumer is to provide

66 This is without prejudice to point (b) of Article 8(2) of DCD.

67 Art. 11 (3) of DCD.

68 Article 11(2), $3^{\text {rd }}$ sentence and Recital 58 of DCD; The Directive provides that Member States remain free to regulate national limitation periods, however, such limitation periods should not prevent consumers from exercising their rights throughout the period of time during which the trader is liable for a lack of conformity. Although, the DCD does not harmonise the starting point of national limitation periods, it ensure that such periods still allow consumers to exercise their remedies for any lack of conformity that becomes apparent at least during the period during which the trader is liable for a lack of conformity.

69 Recital 59 of DCD. 
evidence that the digital content or digital service is not in conformity, but should not have to prove that the lack of conformity existed at the time of supply of the digital content or digital service or, in the event of continuous supply, during the duration of the contract. The burden of proof with regard to whether the supplied digital content or digital service was in conformity at the time of supply, for single or consecutive supplies, is on the trader, for a lack of conformity which becomes apparent within a period of one year from the time of supply. In the cases of continuous supply of digital content or digital services, the burden of proof on conformity within the period of time during which the digital content or digital service was supplied under the contract, is on the trader for a lack of conformity which becomes apparent within that period. ${ }^{70}$ However, this will not be a case where the trader demonstrates that the digital environment of the consumer is not compatible with the technical requirements of the digital content or digital service and where the trader informed the consumer of such requirements in a clear and comprehensible manner before the conclusion of the contract. ${ }^{71}$

The consumer is expected to cooperate in the establishment whether the cause of the lack of conformity lies in the consumer's digital environment. This obligation is limited to the technically available means which are least intrusive for the consumer, especially having in mind their privacy. However, if the consumer fails to cooperate while the trader informed the consumer of such requirement in a clear and comprehensible manner before the conclusion of the contract, the burden of proof is on the consumer. ${ }^{72}$

\section{REMEDIES}

The DCD provides for remedies for the failure to supply ${ }^{73}$ as well as remedies for the lack of conformity. ${ }^{74}$ In both cases, the remedies available reinforce the favor contractus principle as priority is given to the supply of the digital content or digital service i.e., bringing them to conformity. ${ }^{75}$ In principle, the consumer seeks the remedies from the trader. However, in the cases of chain of transactions there might be an act or omission by a person in previous links of that chain that may lead to failure to supply the digital content or digital service, or lack of conformity.

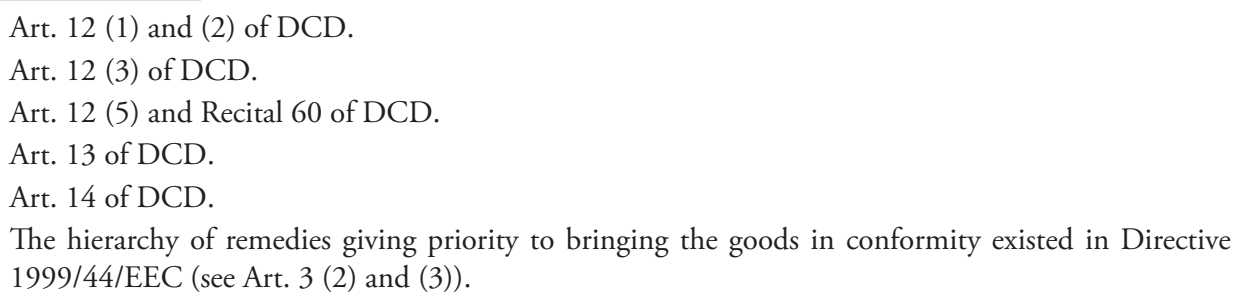


In this case the trader has a right of redress - is entitled pursue remedies against the person or persons liable in the chain of commercial transactions. ${ }^{76,77}$

\subsection{Remedies for failure to supply}

If and when the trader fails to supply the digital content or digital service, the trader shall be liable to the consumer. The consumer is, in that case, entitled: (1) to call upon the trader to supply the digital content or digital service, and (2) to terminate the contract.

The right the consumer to terminate the contract is limited. It may be invoked only if the trader fails to supply the digital content or digital service without undue delay, or within an additional period of time, as expressly agreed to by the parties. ${ }^{78}$ The possibility provided the parties to extend the time of performance confirms the favour contractus principle. Still, the consumer may terminate the contract immediately, only if (a) trader will not supply the digital content or digital service, when this was declared or it is equally clear from the circumstances; and (b) when the specific time for the supply is essential for the consumer, and this was agreed between the parties or it is clear from the circumstances attending the conclusion of the contract. ${ }^{79}$

\subsection{Remedies for lack of conformity}

In the case of a lack of conformity, the consumer is entitled:

1. to have the digital content or digital service brought into conformity,

2. to receive a proportionate reduction in the price, or

3. to terminate the contract, under defined conditions. ${ }^{80}$

The foreseen remedies are not novelty in the EU consumer law. The rules that (currently) exist provide for the same remedies (the 'goods' to be brought into conformity, reduction of price and termination of the contract) ${ }^{81}$ and give priority to bringing the goods in conformity, while the price reduction and termination are on the same level of, so to say, in the hierarchy of the remedies, having

\footnotetext{
76 Art. 20 of DCD.

77 The person against whom the trader may pursue remedies, and the relevant actions and conditions of exercise, are to be determined by national law.

78 Art. 13(1) of DCD.

79 Art. 13 of DCD.

80 Art. 14 (1) of DCD.

81 Art. 3 (2) of Directive 1999/44.
} 
in mind that in the European contract law general hierarchy of remedies in fact does not exist. ${ }^{82}$ It is to be noted, however, that the two-stage hierarchy that exists in the current EU legislation was not mandatory for the Member States, as the Directive 1999/44/EEC was a minimum harmonization directive and there are national legislations where the consumers may choose between remedies is different manner than the one provided in the Consumer Sales Directive. The new legislation, namely this directive and Directive (EU) 2019/770 that repeals the Directive 1999/44/EEC, change this position and require such hierarchy, which is in line with the intention to ensure performance of the trader's/seller's contractual obligation. This, in practice could mean reduction of rights in the jurisdictions where free choice of remedies exists. ${ }^{83}$

\subsubsection{Bringing in to conformity}

The right to have the digital content or digital service brought into conformity ${ }^{84}$, maybe exercised unless this would be impossible or would impose costs on the trader that would be disproportionate. In the assessment of the possibility/the costs all the circumstances of the case are to be taken into account. This includes (a) the value the digital content or digital service would have if there were no lack of conformity; and (b) the significance of the lack of conformity.

The trader is obliged to bring the digital content or digital service into conformity within a reasonable time from the time of receiving the information from the consumer, free of charge and without any significant inconvenience to the consumer ${ }^{85}$. When assessing in practice what a reasonable time would be, one should take into account of the nature of the digital content or digital service and the purpose for which, the consumer required the digital content or digital service.

\subsubsection{Price reduction or termination of the contract}

The consumer may have the price paid for the digital content or digital service, when they supplied in exchange for a payment of a price, reduced or have the

82 See further Schmidt-Kessel, M., Remedies for Breach of Contract in European Private Law, in: Schulze, R. (ed.), New Features in Contract Law, Sellier European Law Publishers, 2007, p. 193.

83 For the specificities of transposition of Art. 3 in the Member States see further Schulte-Nölke, H.; Twigg-Flesner, C.; Ebers, M. (Eds.), EC Consumer Law Compendium, The Consumer Acquis and its transposition in the Member States, Sellier, 2008, p. 427.

84 Art. 14(2) of DCD.

85 Art. 14(3) of DCD. 
contract terminated $^{86}$, in any of the following cases $^{87}$ : (1) when to bring the digital content or digital service into conformity would be impossible or disproportionate; (2) if the trader has not brought the digital content or digital service into conformity; (3) if, despite the trader's attempt to bring the digital content or digital service into conformity, a lack of conformity (still) appears; (4) the nature of the lack of conformity is such as to justify an immediate price reduction or termination of the contract; or (5) if the trader has declared, or it is clear from the circumstances, that the digital content or digital service will not be brought into conformity within a reasonable time, or without significant inconvenience for the consumer.

As to the method for calculation of the reduction, the directive foresees to be proportionate to the decrease in the value of the digital content or digital service supplied, compared to value that it would have had have if it were in conformity. For the digital content or digital service that is supplied over a period of time, the reduction in price applies to the period of time during which the digital content or digital service was not in conformity ${ }^{88}$.

\subsection{Specific rules on termination of the contract as remedy}

The Directive (EU) 2019/770 provides that the contract for supply of digital content or digital service in exchange for the payment of a price, may be terminated only if the lack of conformity is not minor. The burden of proof with regard to whether the lack of conformity is minor is on the trader ${ }^{89}$. The consumer terminates the contract by providing a statement to the trader. ${ }^{90}$

DCD defines the specific rights and obligations of the parties in case of termination of the contract.

\subsubsection{Obligations of the trader}

When it comes to the obligations of the trader in the event of termination the Digital Content Directive provides for specific rules when the supply of the digital content or digital service was in exchange for payment of price and in exchange for personal data.

\footnotetext{
$86 \quad$ Art. 14(4) of DCD.

87 Art. 14(2) of DCD.

88 Art. $14(5)$ of DCD.

89 Art. 14(6) of DCD.

90 Art. 15 of DCD; Rules as to the form of the statement are not provided by DCD.
} 
In the cases of termination of contract where price was paid, the trader is obliged to reimburse the consumer for all sums paid under the contract. When the terminated contract was one that provided continuous supply, the trader reimburses the consumer only for the proportionate part of the price paid corresponding to the period of time during which there was lack of conformity, and any part of the price paid by the consumer in advance for the period that would have remained had the contract not been terminated. ${ }^{91}$ The trader is obliged to make the reimbursement in without undue delay and, in any event, within 14 days of the date of the termination statement. ${ }^{92}$ The reimbursement is to be carried out by using the same means of payment as the consumer used to pay for the digital content or digital service, unless the consumer expressly agrees otherwise, and provided that the consumer does not incur any fees as a result of such reimbursement. In any case, the trader may not impose any fee on the consumer in respect of the reimbursement. ${ }^{93}$

In respect contracts where the supply was in exchange for personal data of the consumer, the trader, as general rule set by the directive, must comply with the obligations stipulated in GDPR. ${ }^{94}$ Digital Content Directive, provides for specific obligations of the trader. Thus, the trader must refrain from using any content other than personal data, which was provided or created by the consumer when using the digital content or digital service supplied by the trader. Exception exists where such content: "(a) has no utility outside the context of the digital content or digital service supplied by the trader; (b) only relates to the consumer's activity when using the digital content or digital service supplied by the trader; (c) has been aggregated with other data by the trader and cannot be disaggregated or only with disproportionate efforts; or (d) has been generated jointly by the consumer and others, and other consumers are able to continue to make use of the content." ${ }^{\prime 5}$ In the cases of content generated jointly with other consumers when using the digital content or digital service supplied by the trader, the trader, at the request of the consumer, is obliged to make available to the consumer any content other than personal data, which was provided or created by the consumer. This retrieval will be free of charge, without hindrance from the trader, within a reasonable time and in a commonly used and machine-readable format. ${ }^{96}$ The trader may prevent any further use of the digital content or digital service by the consumer, in particular

\footnotetext{
91 Art. 16(1) of DCD.

92 Art. 18(1) of DCD.

93 Art. 18(1) and (2) of DCD.

94 Art. 16(2) of DCD.

95 Art. 16(3) of DCD.

96 Art. 16(3) and (4) of DCD.
} 
by making the digital content or digital service inaccessible or disabling the user account of the consumer. ${ }^{97}$

\subsubsection{Obligations of the consumer}

After the termination of the contract, the consumer is no longer permitted to use the digital content or digital service and to make it available to third parties. In the cases, where the digital content was supplied on a tangible medium, the consumer is obliged, at the request and at the expense of the trader, to return the tangible medium to the trader without undue delay. The consumer will have the obligation to return the tangible medium if trader makes the request within 14 days of the day on which the trader is informed of the consumer's decision to terminate the contract. ${ }^{98}$ If the consumer made use of the digital content or digital service which was not in conformity, prior to the termination of the contract, they are not liable to pay for such use. ${ }^{99}$

\subsubsection{Termination due to modification of the digital content or digital service}

Recognising the fact that digital content and digital services have fast-evolving character the DCD address modifications (such as updates and upgrades), carried out by traders on the digital content or digital service which is supplied or made accessible to the consumer over a period of time. In this regard the Directive makes a distinction between modifications that are necessary for (continuous) fulfilment of the objective requirements for conformity and those where the features of the digital content or digital service are modified by decision of the trader beyond what is necessary to maintain the digital content or digital service in conformity. ${ }^{100}$ The first would not only be permitted but also welcomed, but the later would be permitted under specific conditions. Thus, the modifications that are not necessary for conformity will be permitted ${ }^{101}$ if (a) the contract allows, and provides a valid reason for them; (b) they are made without additional cost to the consumer; (c) the consumer is informed in a clear and comprehensible manner of the modification; and (d) if the modification negatively impacts the consumer's access to or use of the digital content or digital service, the consumer is adequately

\footnotetext{
$97 \quad$ Art. 16(5) od DCD.

98 Art. 18(2) of DCD.

99 Art. 18(2) of DCD.

100 Recitals (74) and (75) of DCD.

101 Art. 19(1) of DCD.
} 
informed on such modification. ${ }^{102}$ In the case of negative impact of the modification, the contract may be terminated provided (a) such negative impact is not only minor ${ }^{103}$ and (b) the trader has enabled the consumer to maintain without additional cost the digital content or digital service without the modification, and the digital content or digital service remains in conformity. ${ }^{104}$ The consumer is entitled to terminate the contract free of charge, in a period of 30 days of the receipt of the information on the modification when the modification occurs, whichever is later. ${ }^{105}$ In case of termination due to modification the trader and the consumer have the same rights and obligations as termination due to failure to supply or lack of conformity. ${ }^{106}$

\section{CONCLUDING REMARKS}

The Digital Content Directive was long overdue having in mind the technological development. In determining to which extend it will contribute to regulating the (new) relations between consumers and traders when it comes to supply of digital content and digital services, will largely depend on transposition in the national law of the Member States, by 1 July 2021, and the application of its rules in practice, starting from 1 January 2022. ${ }^{107}$ Having in mind the mandatory nature of the provisions of the directive ${ }^{108}$ as well as its aim to achieve maximum harmonisation ${ }^{109}$ one can expect that the national legislation will not impose obstacles in achieving single digital market in the European Union. However, the success of achieving maximum harmonization of the consumer law by the new directive(s) is questioned and running into difficulties is seen inevitable. ${ }^{110}$ The transposition into the national legislation, as it seems, is not an easy task for the legislators. Although almost 2 years passed since its adoption and only 2 months remain for transposition, so far this was done only in France ${ }^{111}$

102 The consumer should be informed reasonably in advance on a durable medium of the features and time of the modification and of the right to terminate the contract, or of the possibility to maintain the digital content or digital service without such a modification.

103 Art. 19(2) of DCD. This follows the line of reasoning as for the minor lack of conformity (Art.14(6)).

104 Art. 19(4) of DCD.

105 Art. 19(2) of DCD.

106 Art. 19(4) of DCD.

107 Art. 24 of DCD.

108 Art. 22 of DCD.

109 Art. 4 of DCD.

110 Twigg-Flesner, C., Introduction: EU consumer and contract law at a crossroads?, in Twigg-Flesner C. (ed.), Research Handbook on EU Consumer and Contract Law, Edward Elgar Publishing, 2016, p. 9.

111 As provided on EUR-Lex; The transposition in France is made with LOI no 2020-1508 du 3 décembre 2020 portant diverses dispositions d'adaptation au droit de l'Union européenne en matière économi- 
Still, differences in consumer protection on national level will exist, as the DCD does not affect the national law in regards to:

1. formation, validity, nullity or effects of contracts or the legality of the digital content or the digital service; ${ }^{112}$

2. determining the legal nature of contracts for the supply of digital content or a digital service;

3. specific remedies for hidden defects;

4. non-contractual remedies for the consumer, in the event of lack of conformity, against persons in previous links of the chain of transactions, or other persons that fulfil the obligations of such persons; ${ }^{113}$

5. conditions a contract for the supply of digital content or digital services to be considered linked with or ancillary to another contract, the remedies to be exercised under each contract or the effect that the termination of one contract would have on the other contract; ${ }^{114}$

6. consequences for the digital content and digital services contracts in the event that the consumer withdraws the consent for the processing of the consumer's personal data; ${ }^{15}$ and

7. lability of the trader for damages. ${ }^{116}$

Not interfering with the core rules of the contract law is understandable as they are (still) outside of the scope of functions of the European Union. The national rules on liability for damage fall in this category as well, however the differences that exist in the Member States may provide for different level of protection when damages are to be a remedy for a failure to supply digital content and digital service or for lack of conformity. The DCD recognizes that principle of the liability of the trader for damages is an essential element of contracts for the supply of digital content or digital services, as well as entitlement of the consumer ${ }^{117}$ but does not provide any specific rules. It relies on the existing national rules regulating the right to damages for breach of contract. Still, due to the fact that there are "quite significant variations in the way the Member States deal with the availabil-

que et financière, Journal Officiel de la République Française (JORF) [last access 15.04.2021].

112 Art. 3(10) and Recitals (12) DCD.

113 For (1) to (4) as provided in Recitals (12) of DCD.

114 Recital (34) of DCD.

115 Recital (40) of DCD.

116 Art. 3(10) and Recital (40) of DCD.

117 Recital (73) of DCD. 
ity of damages as a remedy"118 differences in consumer protection in this regard are could be expected. In regard to the remedies, it is also to be noted that the introduction of two-stage hierarchy of remedies may mean reduction of rights of the consumers in the jurisdictions where free choice of remedies exists as it was available under Directive 1999/44/EC.

Differences also may occur in regards to the concept of consumer, as the Members States may (or may not) opt the protection to be extended not only co natural persons in the cases of dual-purpose contracts.

The Digital Content Directive and the Sale of Goods Directive confirm the tendency for harmonization, to the maximum effect, of the consumer contract law. How will this affect the 'traditional' understanding of borders (not to be crossed) of the national private law is yet to be seen.

\section{REFERENCES}

\section{BOOKS AND ARTICLES}

1. Beale, H., Scope of application and general approach of the new rules for contracts in the digital environment, European Parliament; Directorate General for Internal Policies; Policy Department C: Citizens' Rights and Constitutional Affairs, PE 536.493

2. Drechsler, L., Data As Counter-Performance: A New Way Forward Or A Step Back For The Fundamental Right Of Data Protection?, in Datenschutz \& LegalTech/ Data Protection \& LegalTech: Digitale Ausgabe zum Tagungsband des 21. Internationalen Rechtsinformatik Symposions IRIS2018 (February ed.)

3. Giliker, P., Adopting a Smart Approach to EU Legislation: Why Has It Proven So Difficult to Introduce a Directive on Contracts for the Supply of Digital Content?, in. Synodinou, T-E.; Jougleux, P.; Markou, C.; Prastitou, T. (eds.), EU Internet Law in the Digital Era Regulation and Enforcement, Springer, 2020

4. Grundmann, S.; Hacker, P., Digital Technology as a Challenge to European Contract Law From the Existing to the Future Architecture (July 17, 2017). 13 European Review of Contract Law 255-293

5. Howells, G.; Twigg-Flesner, C.; Wilhelmsson, T., Rethinking EU Consumer Law, Routledge, 2018

6. Lehmann, M., A Question of Coherence: The Proposals on EU Contract Law Rules on Digital Content and Online Sales, Maastricht Journal of European and Comparative Law, vol. 23, no. 5, 2016

7. Loos, M., European Harmonisation of Online and Distance Selling of Goods and the Supply of Digital Content, Amsterdam Law School Research Paper No. 2016-27, Centre for the Study of European Contract Law Working Paper Series No. 2016-08

118 Howells, G.; Twigg-Flesner, C.; Wilhelmsson, T., Rethinking EU Consumer Law, Routledge, 2018, p. 194. 
8. Morais Carvalho, J., Sale of Goods and Supply of Digital Content and Digital Services - Overview of Directives 2019/770 and 2019/771 (July 18, 2019)

9. Oprysk, L., "Digital" Exhaustion and the EU (Digital) Single Market, in. Synodinou, T-E.; Jougleux, P.; Markou, C.; Prastitou, T. (eds.), EU Internet Law in the Digital Era Regulation and Enforcement, Springer, 2020

10. Rott, P., The EU Legal Framework for the Enforcement of Consumer Law in: Micklitz, H-W.; Saumier, G., Enforcement and Effectiveness of Consumer Law, Ius Comparatum - Global Studies in Comparative Law, Volume 27, Springer, 2018

11. Schmidt-Kessel, M., Remedies for Breach of Contract in European Private Law, in: Schulze, R. (ed.), New Features in Contract Law, Sellier European Law Publishers, 2007

12. Schulte-Nölke, H.; Twigg-Flesner, C.; Ebers, M. (Eds.), EC Consumer Law Compendium, The Consumer Acquis and its transposition in the Member States, Sellier, 2008

13. Twigg-Flesner, C., Introduction: EU consumer and contract law at a crossroads?, in TwiggFlesner C. (ed.), Research Handbook on EU Consumer and Contract Law, Edward Elgar Publishing, 2016

\section{COURT OF JUSTICE OF THE EUROPEAN UNION}

1. Case 120/78 Rewe-Zentral AG v Bundesmonopolverwaltung für Branntwein, [1979] ECR 00649

2. Case C-464/01 Johann Gruber v Bay Wa AG [2005] ECR I-00439

\section{EU LAW}

1. Proposal for a Directive of the European Parliament and of the Council on certain aspects concerning contracts for the supply of digital content; COM/2015/0634 final - 2015/0287 (COD)

2. Proposal for a Directive of the European Parliament and of the Council on certain aspects concerning contracts for the online and other distance sales of goods; COM/2015/0635 final - 2015/0288 (COD)

3. Council Directive $85 / 577 /$ EEC of 20 December 1985 to protect the consumer in respect of contracts negotiated away from business premises, OJ L 372

4. Directive 1999/44/EC of the European Parliament and of the Council of 25 May 1999 on certain aspects of the sale of consumer goods and associated guarantees, [1999] OJ L 171/12

5. Directive 2011/83/EU of the European Parliament and of the Council of 25 October 2011 on consumer rights, amending Council Directive 93/13/EEC and Directive 1999/44/EC of the European Parliament and of the Council and repealing Council Directive 85/577/EEC and Directive 97/7/EC of the European Parliament and of the Council, OJ L 304

6. Regulation (EU) 2016/679 of the European Parliament and of the Council of 27 April 2016 on the protection of natural persons with regard to the processing of personal data and on the free movement of such data, and repealing Directive 95/46/EC (General Data Protection Regulation), OJ L 119 
7. Directive (EU) $2019 / 770$ of the European Parliament and of the Council of 20 May 2019 on certain aspects concerning contracts for the supply of digital content and digital services, OJ L 136

8. Directive (EU) 2019/771 of the European Parliament and of the Council of 20 May 2019 on certain aspects concerning contracts for the sale of goods, amending Regulation (EU) 2017/2394 and Directive 2009/22/EC, and repealing Directive 1999/44/EC, OJ L 136

9. Directive (EU) 2019/2161 of the European Parliament and of the Council of 27 November 2019 amending Council Directive 93/13/EEC and Directives 98/6/EC, 2005/29/EC and 2011/83/EU of the European Parliament and of the Council as regards the better enforcement and modernisation of Union consumer protection rules, OJ L 328

10. Communication from the Commission to the European Parliament, the Council, the European Economic and Social Committee and the Committee of the Regions: A Digital Single Market Strategy for Europe, COM (2015) 192 final.

11. Communication from the Commission to the European Parliament, the Council, and the European Economic and Social Committee: A New Deal for Consumers, Brussels, 11.4.2018 COM (2018) 183 final.

\section{WEB REFERENCES}

1. Internet purchases by individuals (2020 onwards), Eurostat, [https://ec.europa.eu/eurostat/ databrowser/view/isoc_ec_ib20/default/table?lang=en], Accessed 15 March 2021

2. Internet purchases by individuals (until 2019), Eurostat, [https://appsso.eurostat.ec.europa. eu/nui/submitViewTableAction.do], Accessed 15 March 2021

3. Internet purchases - goods or services (2020 onwards), Eurostat, [https://appsso.eurostat. ec.europa.eu/nui/show.do?dataset=isoc_ec_ibgs\&lang=en], Accessed 15 March 2021

4. Internet purchases - money spent (2020 onwards), Eurostat, [https://appsso.eurostat. ec.europa.eu/nui/submitViewTableAction.do], Accessed 15 March 2021

5. E-commerce sales, Eurostat, [https://ec.europa.eu/eurostat/databrowser/view/isoc_ec_eseln2/default/table?lang=en]

6. Accessed 15 March 2021

7. E-commerce in the times of COVID-19, OECD, [https://www.oecd.org/coronavirus/policy-responses/e-commerce-in-the-time-of-covid-19-3a2b78e8/], Accessed 15 March 2021

8. Protecting online consumers during the COVID-19 crisis, OECD, [https://www.oecd. $\mathrm{org} /$ coronavirus/policy-responses/protecting-online-consumers-during-the-covid-19-crisis2ce7353c/], Accessed 15 March 2021 